\title{
Microbicidal Action of Compounds Generated by Transient Electric Arcs in Aqueous Systems
}

\author{
By L. EDEBO*, T. HOLME AND I. SELIN \\ Institute of Medical Microbiology, University of Uppsala, Uppsala, Department of \\ Bacteriology, Karolinska Institutet, Stockholm, and High Voltage Laboratory, \\ Royal Institute of Technology, Stockholm, Sweden
}

(Accepted for publication 29 February 1968)

SUMMARY

Submerged electrical discharges between copper-containing electrodes rendered the treated liquid microbicidal. Part of this activity was unstable and decreased rapidly during the first few minutes. It might have been caused by cuprous ions or substances with oxidative activity. The stable microbicidal activity was due to copper released from the electrodes. This copper existed only partly in ionic form. Inorganic salts and most organic substances tested decreased the bactericidal effect of discharge-treated water. Such substances also diminished the protracted killing effect which was observed when bacteria suspended in water of relatively high purity were subjected to transient electric arcs.

\section{INTRODUCTION}

With high-voltage discharges through water, several physical and chemical effects occur, and micro-organisms present in the discharge liquid are killed. In studies on the mechanism of the killing effect it was shown that the pressure shock-wave alone had no effect (Edebo \& Selin, 1968), while the photon radiation was of great significance (Edebo, I968). It has also been observed that the viable (colony) count decreased considerably with time, when a discharge-treated bacterial suspension was kept at $4^{\circ}$, and that water which had been subjected to discharges had a strong bactericidal effect (Brandt et al. 1962).

\section{METHODS}

The experiments reported in this paper were done with Escherichia coli $\mathbf{\text { B }} 7$ (u.v.resistant) in order to show the killing effect(s) not caused by direct u.v.-radiation. Similar results were obtained with $E$. coli B I 5 (u.v.-sensitive) and the $E$. coli B used in earlier experiments (Edebo \& Selin, 1968; Edebo, 1968).

The electrical equipment and the techniques used for cultivation and making viable (colony) counts were as described by Edebo \& Selin (1968). The same electrical set-up was used in all experiments, namely $C=0.6 \mu \mathrm{F}$., $L=46 \mu \mathrm{H}$., $U=45 \mathrm{kV} ., s=$ I I mm. This gives an energy content of $620 \mathrm{~J}$. per discharge. The volume of liquid treated was $1200 \mathrm{ml}$. The material of the electrodes was different in different experiments.

Determination of the bactericidal effect of water in which discharges had taken place. Samples $(0.05 \mathrm{ml}$.) of a bacterial suspension were pipetted into a series of test-tubes and placed in ice-water. Immediately $(40-60 \mathrm{sec}$.) after the discharge(s) $5 \mathrm{ml}$. of the

* Present address: Institute of Medical Microbiology, University of Lund, Lund, Sweden.

Vol. 52, No. 3, was issued 16 August 1968 
treated liquid were added to each test-tube, and after $\mathrm{I} \mathrm{hr}$ at room temperature (about $18^{\circ}$ ) viable counts were made. The influence of different substances on the bactericidal effect of discharge-treated liquid was studied by adding $5 \mathrm{ml}$. of the liquid immediately after the discharge(s) to $0.05 \mathrm{ml}$. of different solutions in test-tubes. After Io min. at room temperature $0.05 \mathrm{ml}$. of a suspension of bacteria in distilled water was added and after $\mathrm{I} \mathrm{hr}$ at room temperature viable counts were made.

Other analytical procedures. Copper determinations were done by the anodic stripping method (kindly performed by Dr B. Nygård, Pharmacia, Uppsala). Ozone was produced after passing oxygen through an ozonizer (Mark 2, British Oxygen Company, Ltd). Ozone and hydrogen peroxide were determined by iodometry according to Liebknecht \& Katz (1953). Thyodene (Purkis, Williams, London) was used as indicator for iodine.

\section{RESULTS}

When bacteria were suspended in $10^{-4} \mathrm{M}-\mathrm{KCl}$ to a concentration of $3 \times 10^{7}$ viable bacteria $/ \mathrm{ml}$. and subjected to one discharge with copper-tungsten electrodes immersed in the suspension (Fig. I), samples taken less than I min. after the discharge showed approximately $99 \%$ inactivation. When the discharge-treated suspensions were kept in ice-water a slow protracted killing effect was observed which was regular as time proceeded. This effect was much greater than the almost inconspicuous spontaneous death in untreated suspensions. However, the magnitude of the protracted killing effect varied considerably between individual experiments, in which equal volumes of the same bacterial suspension were subjected to one discharge shortly after each other with the same electrical arrangement. After $24 \mathrm{hr}$ one sample gave a viable count of $\mathrm{I} \cdot 3 \times 10^{5}$ bacteria $/ \mathrm{ml}$. while another gave $7 \times 10^{3}$ bacteria $/ \mathrm{ml}$. and similar experiments another day gave less than Io bacteria $/ \mathrm{ml}$.

Aqueous solutions ( $\mathrm{IO}^{-4} \mathrm{M}-\mathrm{KCl}$ ) subjected to electrical discharges had bactericidal activity which increased with the number of discharges. A decrease in the killing effect was observed with lapse of time between discharge and mixing with bacteria (Fig. 2). This decrease was most rapid during the first few minutes after the discharge. After $30 \mathrm{~min}$. the killing effect remained fairly constant for $24 \mathrm{hr}$. In these experiments copper was released from the electrodes into the discharge-treated liquid. One discharge gave the following concentrations (three experiments) $(\mu \mathrm{g} . \mathrm{Cu} / \mathrm{ml}):. \mathrm{I} \cdot 3, \mathrm{I} \cdot 5$, $\mathrm{I} \cdot 7$; two discharges $\mathrm{I} \cdot 4,2 \cdot 3,2 \cdot 4$; three discharges $\mathrm{I} \cdot 8,2 \cdot 8,3 \cdot 8$. Also in these experiments there was considerable variation in the bactericidal effect between solutions treated with the same number of discharges. Each point in Fig. 2 is the average of three experiments; for each experiment viable counts were made in triplicate.

The influence of the electrode material on the killing effect of the discharge-treated liquid was tested with some metals and alloys (Table I). Discharges with electrodes containing copper (copper-tungsten, copper, brass) and silver gave considerable bactericidal activity which increased with increasing numbers of discharges. The average quantity of metal released at one discharge of $620 \mathrm{~J}$. was: with electrodes made from copper, $3.5 \mathrm{mg}$. $\mathrm{Cu}$; from copper-tungsten alloy, $\mathrm{I} \cdot 3 \mathrm{mg}$. $\mathrm{Cu}$ (mainly as copper tungstate). The bactericidal effect of aqueous solutions treated with electrodes from iron, steel, aluminium and platinum was inconspicuous. 


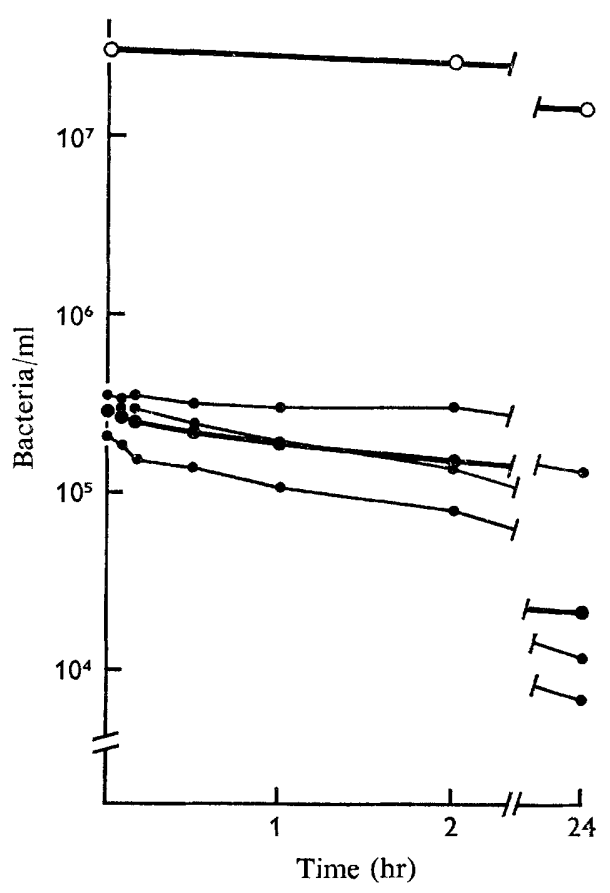

Fig. I

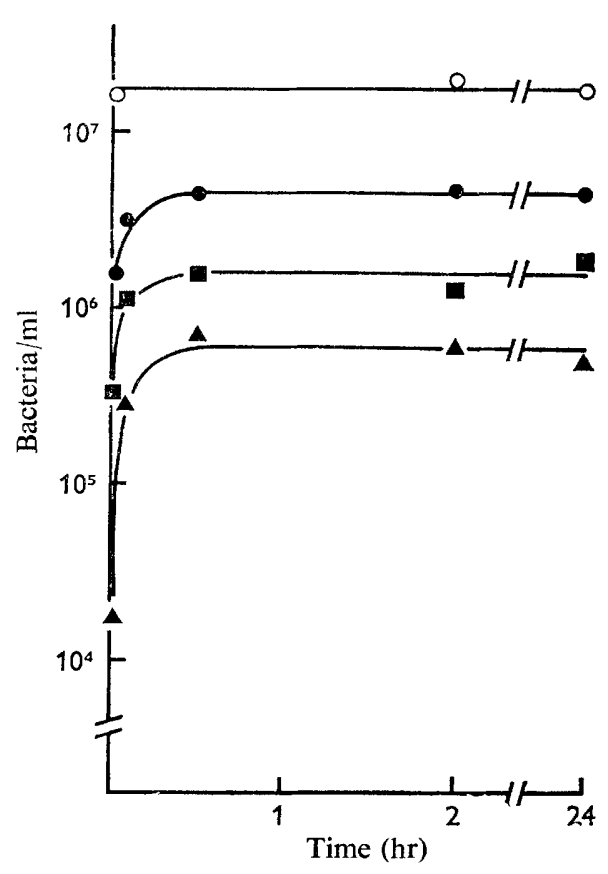

Fig. 2

Fig. I. Survival of Escherichia coli $\mathrm{BI} 7$ present in the discharge-liquid $\left(\mathrm{IO}^{-4} \mathrm{M}-\mathrm{KCl}\right)$ at different intervals after one discharge with copper-tungsten alloy electrodes. Immediately after the discharge part of the suspension was cooled in ice water, and samples for viable count taken from it at different times. $\bigcirc$, No discharge; one discharge representing the average of three different discharge-treated batches (fine lines).

Fig. 2. Bactericidal effect of $10^{-4} \mathrm{M}-\mathrm{KCl}$ treated with discharges with copper-tungsten electrodes on Escherichia coli $\mathbf{B I} 7$ at different times after the discharge(s). $\bigcirc$, No discharge; $\boldsymbol{\bullet}$, one discharge; $\boldsymbol{\square}$, two discharges; $\boldsymbol{\Delta}$, three discharges.

Table I. Effect of the electrode material on the bactericidal effect on Escherichia coli $\mathrm{BI} 7$ of $\mathrm{O} \cdot 000 \mathrm{I} \mathrm{M}-\mathrm{KNO}_{3}$ subjected to discharge(s)

No discharge: $2.0 \times 10^{7}$ bacteria $/ \mathrm{ml}$.

Electrode material

Copper-tungsten

Copper

Brass

Silver

Iron, steel, platinum, or aluminium
Viable count (bacteria/ml.)

$\begin{array}{cc}\text { One discharge } & \text { Five discharges } \\ 7.7 \times 10^{6} & 1.8 \times 10^{4} \\ 7.1 \times 10^{5} & 1.9 \times 10^{3} \\ 4.3 \times 10^{6} & 8.3 \times 10^{5} \\ 1.9 \times 10^{5} & <1.0 \times 10^{1} \\ 1.7 \times 10^{7}-2.0 \times 10^{7}\end{array}$

\section{Addition of different organic and inorganic substances}

Certain organic compounds added to a liquid discharge-treated with copper electrodes influenced its bactericidal effect (Table 2). Cysteine and $\mathrm{Na}$ EDTA decreased, while ascorbic acid increased the killing effect. Glucose slightly decreased the killing effect. 
Inorganic salts inhibited the killing effect. Depending on their neutralizing capacity at $0.0 \mathrm{I} \mathrm{M}$, one series of tested salts were arranged in the following order:

$$
\text { Na-phosphate }>\mathrm{K}_{2} \mathrm{SO}_{4}>\mathrm{KCl}=\mathrm{NaNO}_{3}>\mathrm{CH}_{3} \mathrm{COONH}_{4} \text {. }
$$

As mentioned above, the addition of ascorbic acid increased the killing effect of discharge-treated water when the electrodes contained copper. Also the killing effect

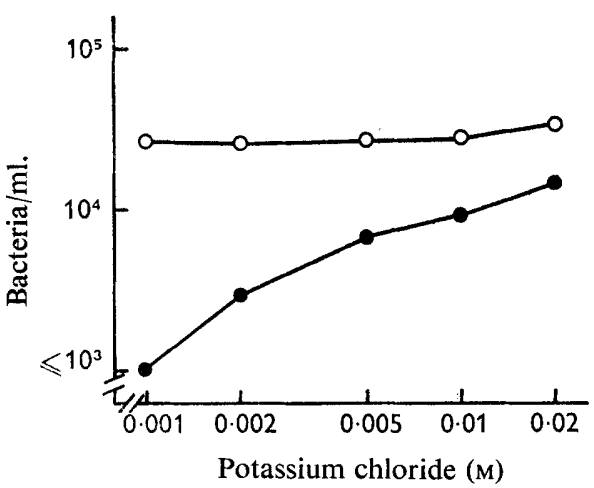

Fig. 3

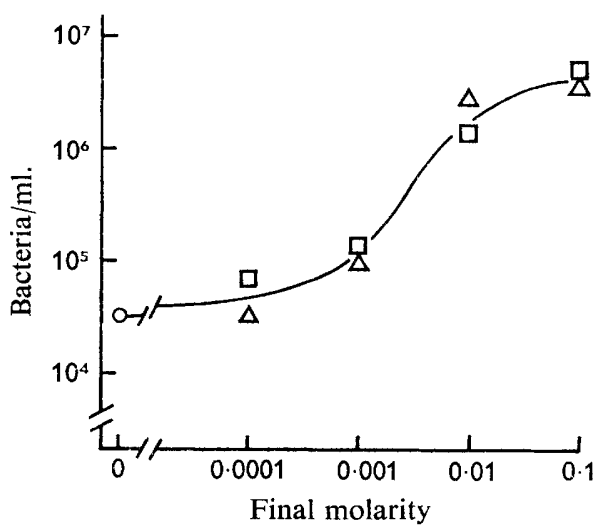

Fig. 4

Fig. 3. Bactericidal effect on Escherichia coli B 17 suspended in different concentrations of $\mathrm{KCl}$ and subjected to one discharge with copper-tungsten electrodes. $\mathrm{O}$, Immediately after the discharge;, after $24 \mathrm{hr}$ at $4^{\circ}$. Untreated suspension $=1 \cdot 9 \times 10^{6}$ bacteria $/ \mathrm{ml}$.

Fig. 4. Escherichia coli в 17 . The influence of different concentrations of salts (final conc.) on the bactericidal effect of $10^{-4} \mathrm{M}-\mathrm{NaCl}$ subjected to three discharges with copper-tungsten electrodes. $\square, \mathrm{KCl} ; \triangle, \mathrm{NaNO}_{3} ; O$, no salt added. Untreated suspension $=\mathrm{I} \cdot 3 \times 10^{2}$ bacteria $/ \mathrm{ml}$.

Table 2. Effect of organic substances on the bactericidal effect on Escherichia coli $B \mathrm{I} 7$ of $0.00 \mathrm{I} \mathrm{M}-\mathrm{KCl}$ subjected to one discharge with copper electrodes

$\begin{array}{lccc}\text { Solution } & \text { Final conc. (M) } & \text { Untreated liquid } & \begin{array}{c}\text { Discharge-treated } \\ \text { liquid }\end{array} \\ \begin{array}{c}\text { Control (distilled } \\ \text { water) }\end{array} & - & 2.4 \times 10^{7} & 4.2 \times 10^{6} \\ \text { Ascorbic acid } & 0.001 & 2.1 \times 10^{7} & 2.0 \times 10^{3} \\ \text { Glucose } & 0.0001 & 2.0 \times 10^{7} & 5.0 \times 10^{3} \\ \text { Na EDTA } & 0.0001 & 2.5 \times 10^{7} & 1.1 \times 10^{7} \\ \text { Cysteine } & 0.00001 & 2.7 \times 10^{7} & 2.8 \times 10^{7} \\ & 0.001 & 2.7 \times 10^{7} & 2.5 \times 10^{7}\end{array}$

of liquid discharge-treated with iron, aluminium or platinum electrodes, which in itself was inconspicuous, was increased, in some cases to more than $99 \%$, when the liquid was mixed with ascorbic acid immediately after the discharge. Ascorbic acid alone had little killing effect.

The influence of salts on the microbicidal effects on bacteria present at the very discharge was tested by subjecting bacteria suspended in a series of concentrations of $\mathrm{KCl}$ to one discharge. Samples were transferred into the diluent containing nutrient 
broth immediately after the discharge and after $24 \mathrm{hr}$ at $4^{\circ}$ (Fig. 3). The instantaneous killing effect was little influenced by concentrations of $\mathrm{KCl}$ of $0.02 \mathrm{M}$ or less. However, at $0.02 \mathrm{M}-\mathrm{KCl}$ the viable counts immediately after the discharge and after $24 \mathrm{hr}$ were nearly identical, while at lower salt concentrations the counts were lower after $24 \mathrm{hr}$. In $0.00 \mathrm{I}-\mathrm{KCl}$ and below no colonies were recovered after $24 \mathrm{hr}$, even when nondiluted suspensions were tested. A similar relation to the concentration was shown for the neutralization of the microbicidal effect of discharge-treated water (Fig. 4). At a concentration of $0.00 \mathrm{I}$ or less of $\mathrm{KCl}$ or $\mathrm{NaNO}_{3}$ there was a marked bactericidal effect, while at $0.01 \mathrm{M}$ and above it was nearly extinguished.

The production of oxidizing substances by discharges was tested by subjecting

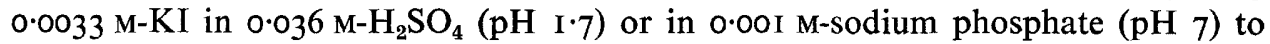
discharges with iron electrodes. The iodine in the discharge-treated liquid was titrated with $\mathrm{Na}_{2} \mathrm{~S}_{2} \mathrm{O}_{3}$. Immediately before the titrations $5 \mathrm{ml}$. of $3.6 \mathrm{M}-\mathrm{H}_{2} \mathrm{SO}_{4}$ and 3 drops of
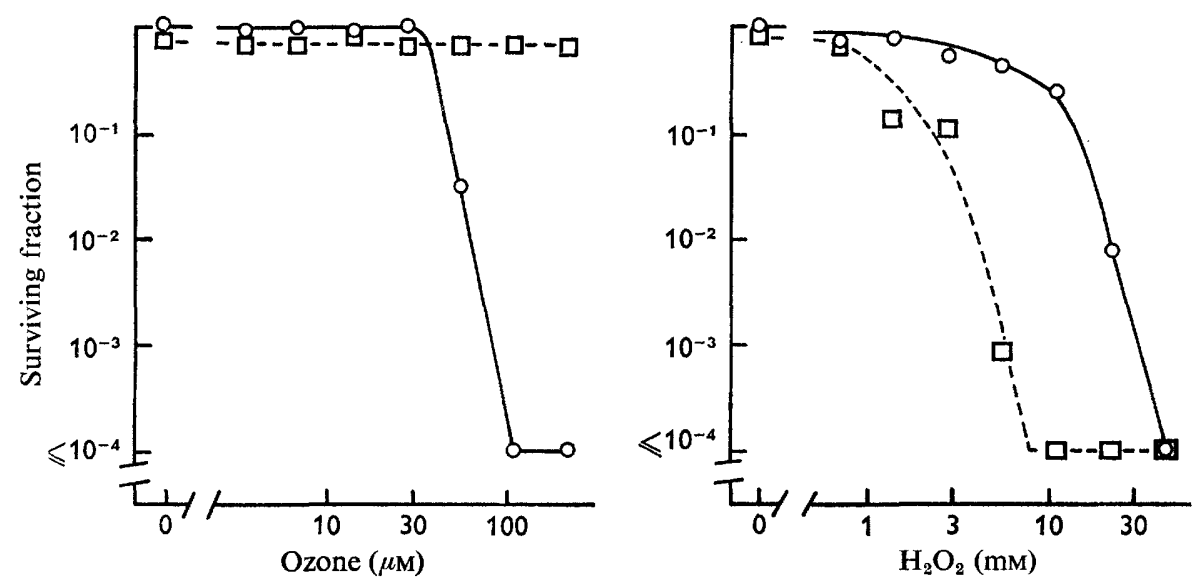

Fig. 5. The bactericidal effect of ozone and hydrogen peroxide on Escherichia coli B I7; $\bigcirc$, oxidant alone; $\square$, mixed with ascorbic acid which had a final conc. of $0.00 \mathrm{I} \mathrm{M.}$

$\mathrm{N}$-ammonium molybdate were added to samples $(30 \mathrm{ml}$.) of the discharge-treated liquid to accelerate the production of iodine. After 40 discharges at $\mathrm{pH} \mathrm{I} \cdot 7$ a concentration of iodine of $3 \cdot 7 \times 10^{-5} \mathrm{M}$ was found. This meant that each discharge caused the production of approximately ${ }_{10}^{-6}$ moles iodine. At $\mathrm{pH} 7$ almost no iodine was found. Bubbling of air at $21 . / \mathrm{min}$. through a fritted glass filter into the same solutions did not produce iodine at either hydrogen-ion concentration.

The bactericidal effect of different concentrations of ozone and hydrogen peroxide was tested alone and in the presence of ascorbic acid (Fig. 5). Ozone was most active alone, while the activity of hydrogen peroxide was enhanced in the presence of ascorbic acid.

\section{DISCUSSION}

Several unstable compounds are produced by the plasma of an electric arc (Martin, 1960; Joncich \& Vaughn, I965; de Mayo, I965). The main products are metallic atoms in various levels of excitation and ionization and reactive oxyhydrogen compounds. Directly or indirectly they may have a microbicidal effect. Some of this effect and 
its decrease with time are illustrated in Fig. 4. Other compounds might have such a short life that only bacteria present at the discharge would be affected.

The fact that the bactericidal effect of discharge-treated liquids was markedly dependent on the electrode metal (Table I) indicated that the electrode material participated in the electrochemical reaction, giving the bactericidal effect. The shortlived highly bactericidal activity displayed by the liquids immediately after the discharge-treatment (Fig. 2), when the electrodes contained copper, might be produced by an activated state of liberated copper or by other unstable compounds generated by the discharge. Liquid discharge-treated with any kind of electrode material tested and then mixed with ascorbic acid had bactericidal activity. Since ascorbic acid mixed with an oxidant has high microbicidal activity, particularly in the presence of copper (Ericsson \& Lundbeck, I955), it was supposed that the unstable microbicidal effect of discharge-treated water was caused by substances with oxidative activity generated at the discharge. This supposition was supported by the oxidation of KI by discharges. This activity was more like that of hydrogen peroxide than of ozone in being capable of oxidizing $\mathrm{KI}$ at $\mathrm{pH} \times \cdot 7$ but not at $\mathrm{pH} 7$ (Liebknecht \& Katz, I953) and in increasing its bactericidal effect in the presence of ascorbic acid (Fig. 5). However, it seemed to be more bactericidal at the same oxidative capacity and more unstable than hydrogen peroxide. Another possible explanation of the rapid decrease of the bactericidal activity after a discharge in water with copper-containing electrodes is that cuprous ions which are formed during the discharge (Martin, 1960) are oxidized to cupric ions or disproportionate to give cupric ions and metallic copper (Hemmerich, 1966) which both are of lower bactericidal activity (Cramp, 1967). Ascorbic acid regenerates cuprous ions (Zimmerman, 1966). The two proposed mechanisms do not exclude each other; nor can we exclude that trace amounts of non-recognized substances play a role.

The protracted bactericidal effect, which remained fairly constant for at least $24 \mathrm{hr}$, was probably due to metal released from the electrodes during the discharge. At the same concentration of copper, 24 -hr old discharge-treated liquid had less bactericidal activity than solutions of $\mathrm{CuCl}_{2}$. Presumably not all the copper released by the discharges was ionized; electric arcs have been used to produce colloidal suspensions of metals and metal oxides (Svedberg, 1909).

Inorganic salts and some organic compounds decreased the bactericidal effect of liquid discharge-treated with electrodes containing copper (Table 2). Both inorganic and organic substances decrease the oligodynamic activity of silver (Süpfle \& Werner, I954). EDTA forms a strong chelate, and cysteine forms mercaptides with copper ions, which might explain their neutralizing effect. Since the neutralizing effect of the inorganic salts seemed to be dependent on their ionic strength, and bacteria behave as ion exchangers (Edebo, 196I), the effect of inorganic salts might be a consequence of competition for and screening of vital groups by the innocuous ions to keep toxic copper ions away. The bactericidal effect of ozone and hydrogen peroxide obtained in our experiments (Fig. 5) agreed with earlier published data (Ingram \& Haines, 1949; Ingram \& Barnes, 1954; Wallhäuser \& Schmidt, 1967). Many organic substances neutralize both compounds, and inorganic salts increase the velocity of decomposition of ozone (Ingram \& Barnes, I954). Consequently, organic substances and inorganic salts might also counteract the oxidizing effect of discharge-treated water. At salt concentrations where no bactericidal activity was found in liquids discharge-treated with electrodes containing copper (Fig. 4), little or no protracted killing effect was 
observed (Fig. 3). This makes it likely that most if not all of the protracted bactericidal effect was caused by compounds generated at the discharge. This might also explain why generally little or no protracted killing effect was found after discharge-treatment of tap water.

After submitting this communication two papers (Gilliland \& Speck, 1967a,b) were seen which showed the presence of copper in the discharge-liquid after discharges with copper electrodes and the oxidation of several biological substances by submerged discharges with aluminium electrodes. These investigators were using higher capacitances $(6-24 \mu \mathrm{F}$.) and lower voltage (1o kV.). Their results indicate, however, that similar or identical mechanisms of killing operate.

This work was made possible by grants from Grängesbergsbolaget, Sweden. The assistance provided by Miss Lillemor Svensk and Mr Mahendra Pal Singh is gratefully acknowledged.

\section{REFERENCES}

Brandt, B., Edebo, L., Hedén, C.-G., Huortzberg-Nordlund, B., Selin, I. \& Tigerschiöld, M. (1962). The effect of submerged electrical discharges on bacteria. TVF 33, 222.

CRAMP, W. (1967). The toxic action on bacteria of irradiated solutions of copper compounds. Rad. Res. 30, $22 \mathrm{I}$.

EDEBo, L. (1961). Lysis of bacteria. 2. Studies on the mechanisms involved in mechanical lysis. Acta path. microbiol. scand. 52, 384 .

EDEBO, L. (1968). The effect of the photon radiation in the microbicidal effect of transient electric arcs in aqueous systems. J. gen. Microbiol. 50, 261.

Edebo, L. \& Selin, I. (I968). The effect of the pressure shock wave and some electrical quantities in the microbicidal effect of transient electric arcs in aqueous systems. J. gen. Microbiol. 50, 253.

Ericsson, Y. \& LundBeck, H. (I955). Antimicrobial effect in vitro of the ascorbic acid oxidation. Acta path. microbiol. scand. 37, 493, 507.

GiLliLAND, S.E. \& SPECK, M. L. (1967a). Inactivation of micro-organisms by electrohydraulic shock. Appl. Microbiol. 15, 1031.

GilliLAND, S. E. \& SPECK, M. L. $(1967 b)$. Mechanism of bactericidal action produced by electrohydraulic shock. Appl. Microbiol. r5, 1038.

HeMmerich, P. (1966). Model studies on the binding of univalent and redox-active copper in proteins. In The Biochemistry of Copper. Ed. J. Peisach, P. Aisen and W. E. Blumberg, p. I5. New York: Academic Press.

INGRAM, M. \& BARNes, E. (1954). Sterilization by means of ozone. J. appl. Bact. 17, 246.

InGRAM, M. \& HAINES, R. B. (I949). Inhibition of bacterial growth by pure ozone in the presence of nutrients. J. Hyg., Camb. 47, I46.

Joncich, M. \& VaUGHN, J. (1965). Chemistry at I million ${ }^{\circ} \mathrm{K}$. New Scient. 25, $7 \mathrm{I} 6$.

LIEBKNECHT, O. \& KATZ, W. (1953). Ozon: Wasserstoffperoxyd einschliesslich der anorganischen und organischen Perverbindungen (ohne Blei). In Fresenius \& Jander, Handbuch der Analytischen Chemie, Dritter Teil, Band VI a $\propto$ I, pp. I I6, 170, 210. Berlin: Springer Verlag.

MARTIN, E. A. (1960). Experimental investigation of a high-energy density, high-pressure arc plasma. J. appl. Physics, 31, 255.

De Mayo, P. (1965). Chemistry and light. New Scient. 26, 289.

SÜPFLE, K. \& WERnER, R. (1954). Quoted from Antiseptics, Disinfectants, Fungicides and Sterilization. (I954) Ed. G. F. Reddish. Philadelphia: Lea \& Febiger.

SvedBeRg, THE (1909). Herstellung Kolloider Lösungen Anorganischer Stoffe. Dresden: Verlag von Theodor Steinkopff.

WallhäUSER, K. H. \& SChmidt, H. (1967). Sterilisation, Desinfektion, Konservierung, Chemotherapie. Stuttgart: G. Thieme.

Zimmerman, L. (1966). Toxicity of copper and ascorbic acid to Serratia marcescens. J. Bact. 9I, I537.

(First received 6 November 1967 ) 